\title{
Działania organów administracji publicznej w odniesieniu do obiektów budowlanych podczas ich użytkowania
}

\begin{abstract}
Robert Lenarcik
Lubelski Wojewódzki Inspektor Nadzoru Budowlanego,

Wojewódzki Inspektorat Nadzoru Budowlanegow Lublinie, e-mail: sekretariat@lublin.winb.gov.pl

Streszczenie: Referat rozpoczyna się wstępem, w którym zwarte są podstawowe zasady, na których oparte są działania organów administracji publicznej. Następnie omówiona jest właściwość rzeczowa organów oraz podstawowe obowiązki wynikające z przepisów prawa materialnego tj. ustawy Prawo budowlane. W dalszej części, omówiono działania organów nadzoru budowlanego w odniesieniu do obiektów budowlanych podczas ich użytkowania, które pogrupowano na działania proceduralne i niezwłoczne. Kończąc, wskazano na czynniki wpływające na działania organów nadzoru budowlanego oraz zawarto krótkie podsumowanie referatu.
\end{abstract}

Słowa kluczowe: administracja publiczna, właściwości, obowiązki, działania.

\section{Wstęp}

Każde działanie organów administracji publicznej, powinno opierać się na podstawowej zasadzie: „zasadzie praworządności”. Jest ona określona w art. 7 Konstytucji Rzeczypospolitej Polskiej z dnia 2 kwietnia 1997 r. (Dz. U. Nr 78, poz. 483 z późn. zm.), który stanowi, że: „Organy władzy publicznej działają na podstawie i w granicach prawa”. Zasada ta zawarta jest również w art. 6 ustawy z dnia 14 czerwca 1960 r. Kodeks postępowania administracyjnego (tekst jednolity Dz. U. z 2013 r. poz. 47 z późn. zm.), dalej określana w skrócie, jako Kpa. Wskazuje ona jednoznacznie, że: „Organy administracji publicznej działają na podstawie przepisów prawa". Działanie na podstawie przepisów prawa, wiąże się z kolei z koniecznością zachowania kolejnej zasady wynikającej z ww. ustawy, a mianowicie, zachowania „zasady przestrzegania właściwości”, która została zawarta w art. 19 Kpa, mówiącym, że: „Organy administracji publicznej przestrzegają z urzędu swojej właściwości rzeczowej i miejscowej”. Powaga przestrzegania „swojej właściwości rzeczowej i miejscowej” jest jedną z najważniejszych zasad w działalności organów administracji publicznej, bowiem „Naruszenie każdego rodzaju właściwości przez organ administracji przy wydawaniu decyzji administracyjnej powoduje nieważność decyzji bez względu na trafność merytorycznego rozstrzygnięcia. Przepisy o właściwości mają, zatem, charakter bezwzględnie obowiązujący, a organy z urzędu muszą przestrzegać swojej właściwości"(zob. wyrok Wojewódzkiego Sądu Administracyjnego siedziba w Warszawie z dnia 10 czerwca 2013 r. IV SA/Wa 811/13). 


\section{Wlaściwości i obowiązki organów administracji publicznej}

\subsection{Właściwość rzeczowa}

Właściwość rzeczowa została sprecyzowana w art. 20 Kpa, który stanowi, że: „Właściwość rzeczową organu administracji publicznej ustala się według przepisów o zakresie jego działania". Na tej podstawie dochodzimy do merytorycznych przepisów związanych z działalnością organów administracji publicznej w odniesieniu do obiektów budowlanych podczas ich użytkowania. Ustawa z dnia 7 lipca 1994 r. Prawo budowlane (Dz.U. z 2010 r. nr 243, poz. 1623 z późn. zm.), w art. 1 mówi: „Ustawa - Prawo budowlane, zwana dalej "ustawą", normuje działalność obejmującą sprawy projektowania, budowy, utrzymania i rozbiórki obiektów budowlanych oraz określa zasady działania organów administracji publicznej w tych dziedzinach".

\subsection{Ustawowe obowiązki organów administracji publicznej}

Nie można rozdzielić kwestii związanej z działalnością organów administracji publicznej od obowiązków wskazanych z ustawie merytorycznej.

Przepisy prawne związane z utrzymaniem obiektów budowlanych, zawarte są w rozdziale 6 ustawy Prawo budowlane. Na mocy art. 83 cytowanej ustawy, kompetencje związane z utrzymaniem obiektów budowlanych należą do służb nadzoru budowlanego, z wyjątkiem kompetencji służb architektoniczno - budowlanych dotyczących przyjmowania zgłoszeń związanych ze zmianą sposobu użytkowania obiektów budowlanych.

\section{Działania organów nadzoru budowlanego w odniesieniu do obiektów budowlanych podczas ich użytkowania}

\subsection{Dzialania proceduralne i działania niezwłoczne}

Podstawą działania służb nadzoru budowlanego są czynności kontrolne, ponieważ zgodnie z art. 81 ust. 4 Prawa budowlanego: „Organy administracji architektonicznobudowlanej i nadzoru budowlanego przy wykonywaniu obowiązków określonych przepisami prawa budowlanego mogą dokonywać czynności kontrolnych. Protokolarne ustalenia dokonane $\mathrm{w}$ toku tych czynności stanowią podstawę do wydania decyzji oraz podejmowania innych środków przewidzianych w przepisach prawa budowlanego", jednak tylko: "Organy nadzoru budowlanego lub osoby działające z ich upoważnienia mają prawo wstępu: ... do obiektu budowlanego" (art. 81a ust. 1 pkt 1). Czynności kontrolne można podzielić na: kontrole prewencyjne (prowadzone w ramach planowanych harmonogramów kontroli), sprawdzające (przeprowadzane w związku z pozyskaną informacją) i na oględziny (wyznaczane w ramach wszczętego postępowania administracyjnego).

\subsubsection{Dziatania proceduralne}

Działania proceduralne, czyli oparte na regułach określających prawne ramy postępowania, wskazane w przepisach Kpa, wynikają z ogólnej zasady związanej z obowiązkiem organu do zapewnienia stronom czynnego udziału w każdym stadium postępowania i zakończenia postępowania orzeczeniem administracyjnym. Należy zaznaczyć, że w postępowaniach dotyczących utrzymania obiektów budowlanych, zazwyczaj stroną postępowania jest tylko właściciel lub zarządca obiektu. Właściciel (lub zarządca) jest obowiązany: utrzymywać i użytkować obiekt zgodnie z zasadami, o których mowa w obowiązujących 
przepisach, a co najważniejsze, winien go użytkować w sposób zgodny z jego przeznaczeniem i wymaganiami ochrony środowiska oraz utrzymywać w należytym stanie technicznym i estetycznym, nie dopuszczając do nadmiernego pogorszenia jego właściwości użytkowych i sprawności technicznej. Aby wypełnić ten obowiązek, obiekty budowlane powinny być $\mathrm{w}$ czasie ich użytkowania poddawane przez właściciela lub zarządcę kontrolom okresowym. Częstotliwość i zakres kontroli określają stosowne przepisy ustawy Prawo budowlane. Działania organów nadzoru budowlanego podejmowane są w sytuacji, gdy w wyniku kontroli stwierdza się, że zobowiązane strony nie przeprowadzają kontroli okresowych, w wyniku czego obiekt doprowadzany jest do nieodpowiedniego stanu technicznego. Wówczas, na mocy art. 62 ust. 3 ustawy z dnia 7 lipca 1994 r. - Prawo budowlane: „Właściwy organ - w razie stwierdzenia nieodpowiedniego stanu technicznego obiektu budowlanego lub jego części, mogącego spowodować zagrożenie: życia lub zdrowia ludzi, bezpieczeństwa mienia bądź środowiska - nakazuje przeprowadzenie kontroli, o której mowa w ust. 1, a także może żądać przedstawienia ekspertyzy stanu technicznego obiektu lub jego części. W razie powstania uzasadnionych wątpliwości, co do stanu technicznego obiektu budowlanego, organy nadzoru budowlanego mogą również nałożyć, w drodze postanowienia, na właściciela lub zarządcę obiektu budowlanego, obowiązek dostarczenia w określonym terminie odpowiednich ocen technicznych lub ekspertyz. Koszty ocen i ekspertyz ponosi osoba zobowiązana do ich dostarczenia (art. 81c ust. 2).

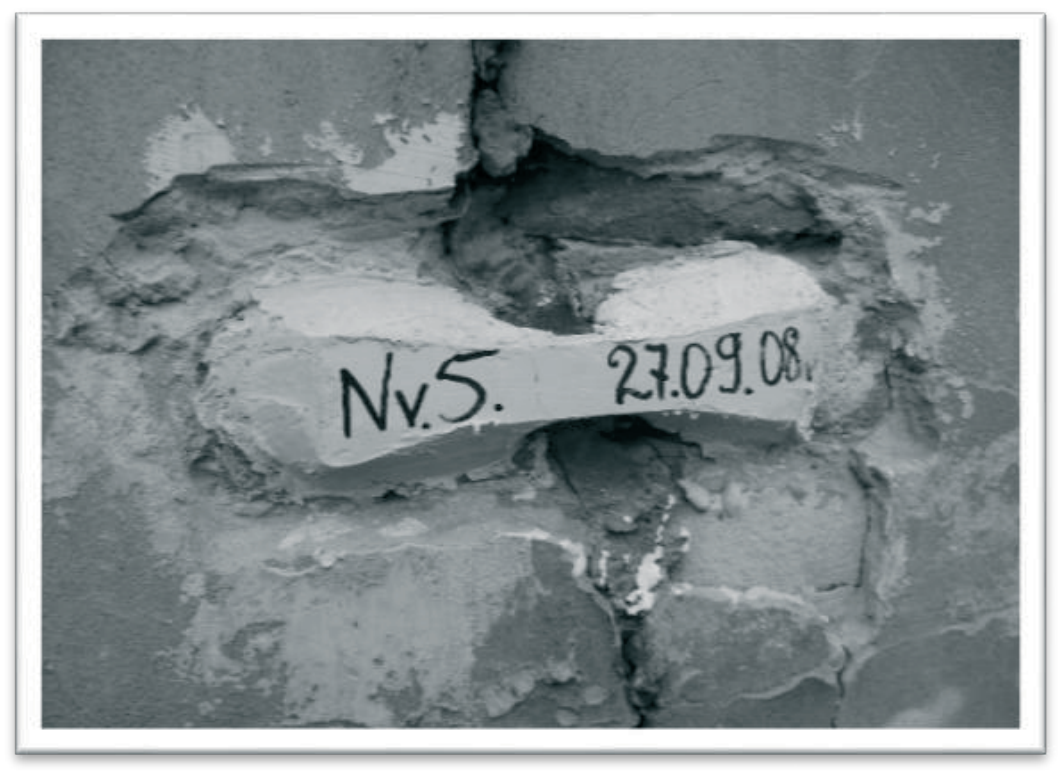

Rys. 1. Założona plomba gipsowa po kontroli okresowej przeprowadzonej przez zarządcę obiektu

Należy w tym miejscu zaznaczyć, że zgodnie z nowelizacją ustawy Prawo budowlane, która obowiązuje od 7 stycznia 2016 r., ustawodawca wprowadził zmiany do art. 62, których zadaniem jest ochrona lokatorów. Nowy przepis art. 62 ust. 4a stanowi, że: „W przypadku zgłoszenia przez osoby zamieszkujące lokal mieszkalny znajdujący się w obiekcie budowlanym o dokonaniu nieuzasadnionych względami technicznymi lub użytkowymi ingerencji lub naruszeń, powodujących, że nie są spełnione warunki określone w art. 5 ust 2; ", po ust. 2 dodano nowy ust. 2a, w brzmieniu: „Kontrolę, o której mowa w ust. 1 pkt $4 \mathrm{a}$, właściciel lub zarządca jest zobowiązany przeprowadzić w terminie 3 dni 
od otrzymania zgłoszenia.” Następne działania podejmowane są w przypadkach, gdy podczas kontroli stanu technicznego obiektu budowlanego, służby nadzoru budowlanego stwierdzą, że może zagrażać on życiu lub zdrowiu ludzi, bezpieczeństwu mienia bądź środowiska albo, jest użytkowany w sposób zagrażający życiu lub zdrowiu ludzi, bezpieczeństwu mienia lub środowisku, albo, jest w nieodpowiednim stanie technicznym, bądź powoduje swym wyglądem oszpecenie otoczenia.

Wówczas, właściwy organ nakazuje, w drodze decyzji, usunięcie stwierdzonych nieprawidłowości, określając termin wykonania tego obowiązku.

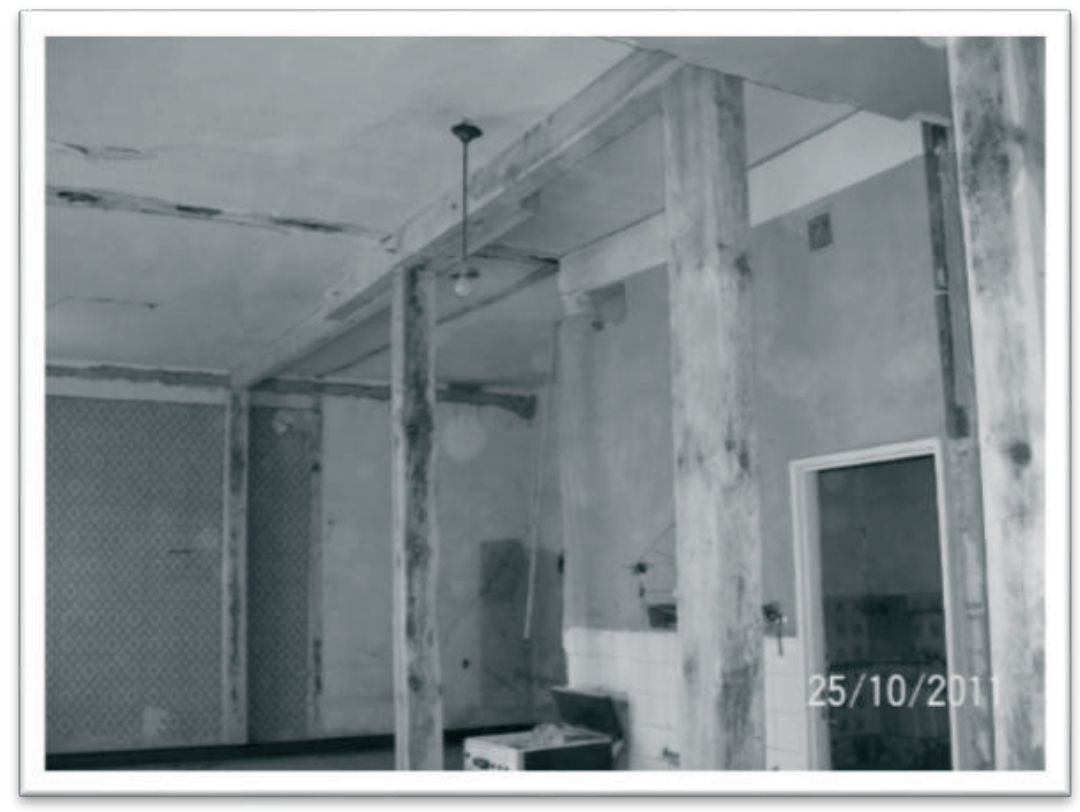

Rys. 2. Wykonanie nakazu podstemplowania stropu budynku

Jeżeli wystąpią trzy pierwsze okoliczności, w decyzji, właściwy organ może zakazać użytkowania obiektu budowlanego lub jego części do czasu usunięcia stwierdzonych nieprawidłowości. Jak wspomniałem wcześniej, od 7 stycznia 2016 r. znowelizowana ustawa Prawo budowlane wprowadziła nowy obowiązek dla służb nadzoru budowlanego, wynikający z art. 66 ust. 1a, który mówi że: „W przypadku stwierdzenia nieuzasadnionych względami technicznymi lub użytkowymi ingerencji lub naruszenia wymagań dotyczących obiektu budowlanego, których charakter uniemożliwia lub znacznie utrudnia użytkowanie go do celów mieszkalnych, organ nadzoru budowlanego nakazuje, w drodze decyzji, usunięcie skutków ingerencji lub naruszeń lub przywrócenie stanu poprzedniego. Decyzja podlega natychmiastowemu wykonaniu i może być ogłoszona ustnie". Dalsze proceduralne działania organów nadzoru budowlanego, wynikające z kompetencji określonych w ustawie Prawo budowlane, dotyczą obiektów nieużytkowanych, nienadających się do remontu. Mianowicie, przepis art. 67 ust. 1-3 cytowanej ustawy stanowi, że „Jeżeli nieużytkowany lub niewykończony obiekt budowlany nie nadaje się do remontu, odbudowy lub wykończenia, właściwy organ wydaje decyzję nakazującą właścicielowi lub zarządcy rozbiórkę tego obiektu i uporządkowanie terenu oraz określającą terminy przystąpienia do tych robót i ich zakończenia. Przepisu nie stosuje się do obiektów budowlanych wpisanych do rejestru zabytków. W stosunku do obiektów niewpisanych do rejestru zabytków, a objętych ochroną 
konserwatorską na podstawie miejscowego planu zagospodarowania przestrzennego, decyzję, o której mowa w ust. 1, właściwy organ wydaje po uzgodnieniu z wojewódzkim konserwatorem zabytków". Ostatnie działanie, związane jest ze stanem technicznym budynku, który grozi zawaleniem. W razie stwierdzenia potrzeby opróżnienia w całości lub w części budynku przeznaczonego na pobyt ludzi, bezpośrednio grożącego zawaleniem, właściwy organ jest obowiązany: nakazać, w drodze decyzji, na podstawie protokołu oględzin, właścicielowi lub zarządcy obiektu budowlanego opróżnienie bądź wyłączenie w określonym terminie całości lub części budynku z użytkowania, przesłać decyzję, o której mowa, obowiązanemu do zapewnienia lokali zamiennych na podstawie odrębnych przepisów, zarządzić umieszczenie na budynku zawiadomienia o stanie zagrożenia bezpieczeństwa ludzi lub mienia oraz o zakazie jego użytkowania, wykonanie doraźnych zabezpieczeń i usunięcie zagrożenia bezpieczeństwa ludzi lub mienia, z określeniem, technicznie uzasadnionych, terminów ich wykonania.

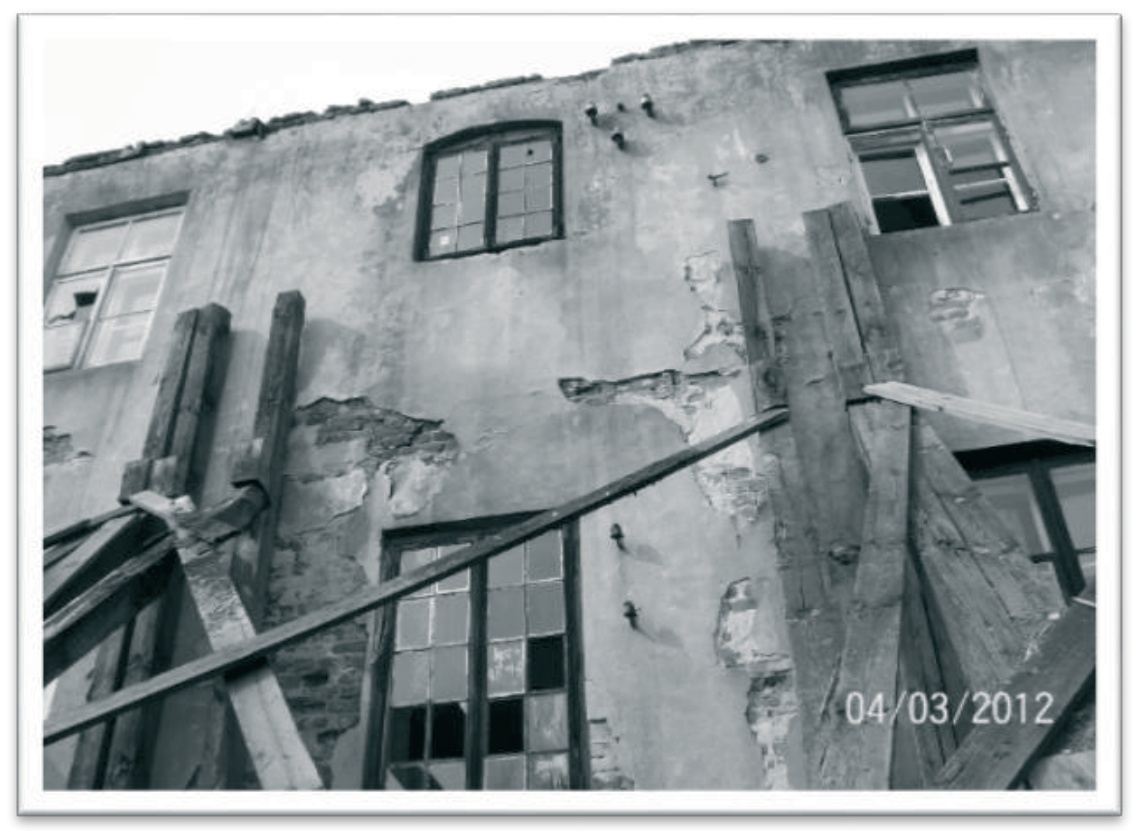

Rys. 3. Wykonanie nakazu podstemplowania ściany w budynku wyłączonym z użytkowania

\subsubsection{Dzialania niezwloczne}

Działania niezwłoczne, charakteryzują się cechą pominięcia procedur administracyjnych. Organy mogą odstąpić od tej zasady tylko w przypadkach, gdy załatwienie sprawy nie cierpi zwłoki ze względu na niebezpieczeństwo dla życia lub zdrowia ludzkiego albo ze względu na grożącą niepowetowaną szkodę materialną (art. 10 § 1 i $~ 2 \mathrm{Kpa}$ ).

Pierwsze działanie, wynika z obowiązku wskazanego w art. 70 ust. 1 (po nowelizacji) i ust. 2 ustawy Prawo budowlane. Stanowi on, że: „Właściciel, zarządca lub użytkownik obiektu budowlanego, na których spoczywają obowiązki w zakresie napraw, określone w przepisach odrębnych bądź umowach, są obowiązani w czasie lub bezpośrednio po przeprowadzonej kontroli, o której mowa w art. 62 ust. 1 pkt 1-4a (kontroli okresowych), usunąć stwierdzone uszkodzenia oraz uzupełnić braki, które mogłyby spowodować zagrożenie życia lub zdrowia ludzi, bezpieczeństwa mienia bądź środowiska, a w szczególności kata- 
strofę budowlaną, pożar, wybuch, porażenie prądem elektrycznym albo zatrucie gazem." Właściwy organ, po otrzymaniu kopii protokołu, przeprowadza bezzwłocznie kontrolę obiektu budowlanego w celu potwierdzenia usunięcia stwierdzonych uszkodzeń oraz uzupełnienia braków, o których mowa w ust. 1".

Kolejne działanie, związane jest z art. 69 ust. 1 i 2 omawianej ustawy. Zgodnie z jego znowelizowaną treścią: „W razie konieczności niezwłocznego podjęcia działań mających na celu usunięcie niebezpieczeństwa dla ludzi lub mienia, lub ingerencji lub naruszeń, o których mowa w art. 66 ust. 1a, właściwy organ zapewni, na koszt właściciela lub zarządcy obiektu budowlanego, zastosowanie niezbędnych środków zabezpieczających”. Do zastosowania, na koszt właściciela lub zarządcy, środków przewidzianych w przytoczonym przepisie, są upoważnione również organy Policji i Państwowej Straży Pożarnej. O podjętych działaniach organy te powinny niezwłocznie zawiadomić właściwy organ.

\section{Czynniki wpływające na działania organów nadzoru budowlanego w odniesieniu do obiektów budowlanych podczas ich użytkowania}

Podstawowym czynnikiem, który wpływa na zakres podejmowanych działań przez służby nadzoru budowlanego, jest fakt niewywiązywania się przez właścicieli lub zarządców z obowiązków związanych z przeprowadzaniem kontroli okresowych stanu technicznego obiektów budowlanych, w trakcie ich użytkowania. Często nadzór budowlany stwierdza się, że kontrole okresowe nie są wykonywane rzetelnie (w niepełnym zakresie określonym dla danej kontroli, nie jest sprawdzane wykonanie zaleceń z kontroli poprzedniej, protokoły z kontroli obiektów wielkopowierzchniowych nie są przekazywane do służb nadzoru budowlanego). Następnym zjawiskiem, które wpływa na stan techniczny obiektu i determinuje działania właściwych służb, to samowolne wykonywanie robót budowlanych, które ingerują w istniejącą strukturę obiektu, naruszając jego konstrukcję. Podobna sytuacja występuje w trakcie prowadzenia robót budowlanych w bezpośrednim sąsiedztwie obiektu. Często opracowana dokumentacja budowlana nie uwzględnia, w dostatecznym zakresie, wpływu tej inwestycji na stan techniczny sąsiedniego obiektu. Bardzo poważnym problem, utrudniającym działania organów nadzoru budowlanego, jest fakt nieuregulowania spraw własnościowych nieruchomości, na której usytuowany jest obiekt znajdujący się w złym stanie technicznym. W takich przypadkach, gdy obiekt nie ma ustanowionego prawnego właściciela (lub zarządcy), organ nie może w decyzji wskazać strony, którą należy zobowiązać do usunięcia nieprawidłowości.

\section{Podsumowanie}

Każde działanie służb nadzoru budowlanego związane z użytkowaniem obiektów budowlanych, powinno zmierzać do jednego zasadniczego celu - niedopuszczenie do powstania i eliminowanie stanu zagrożenia życia ludzi i bezpieczeństwa mienia, w związku z użytkowaniem obiektów budowlanych. Taki stan występuje z reguły w przypadkach eksploatowania obiektów bez bieżącej kontroli stanu technicznego, lub w sytuacji, gdy obiekt nie ma prawnego właściciela. Dlatego w służbach nadzoru budowlanego muszą być zatrudnione osoby posiadające odpowiednie uprawnienia budowlane, a więc posiadające stosowną wiedzę i doświadczenie zawodowe, uprawniające do dokonywania właściwej oceny zjawisk, występujących na obiektach budowlanych w trakcie ich użytkowania. 


\title{
Literatura
}

1. Konstytucja Rzeczypospolitej Polskiej z dnia 2 kwietnia 1997 r. (Dz. U. Nr 78, poz. 483 z późn. zm.).

2. Ustawa z dnia 14 czerwca $1960 \mathrm{r}$. Kodeks postępowania administracyjnego (tekst jednolity Dz. U. z 2016 r. poz. 23.).

3. Wyroki sądów administracyjnych - LEGALIS System Informacji Prawnej.

4. Ustawa z dnia 7 lipca 1994 r. Prawo budowlane (Dz.U. z 2010 r. nr 243, poz. 1623 z późn. zm.).

\section{The actions of public administration bodies regarding building objects during their exploitation}

\author{
Robert Lenarcik \\ Main Construction Site Inspector of Lublin Voivodeship, \\ Construction Site Inspectorate of Lublin Voivodeship
}

\begin{abstract}
The paper begins with the introduction, which contains basic rules, that the action of public administration bodies is based on. Next, it factual adequateness and fundamental duties resulting from the material law are described, that is Construction Law. In the further part, it is written about the actions of construction site bodies, regarding to building objects during their usufruct, that were grouped in procedural and immediate ones. At the end, factors affecting the action of construction site bodies were indicated and a short paper's summary was attached.
\end{abstract}

Keywords: public administration, properties, duties, actions. 
